\title{
The Yorkshire Dialect Representation in Wuthering Heights and Jane Eyre by Emily and Charlotte Brontë
}

\author{
Khadidja Layadi - Mouffak \\ Department of English \\ Faculty of Foreign Languages \\ University of Oran2 Mohamed BenAhmed, Algeria
}

\begin{abstract}
The use of dialect is common in literature. Sometimes writers are making use of the language of speech within the language of writing, the standard language. In this paper the researcher will not consider any dialect linguistically inferior to any other. Therefore, the present humble contribution is an attempt to investigate the motivations underlying the tendency for dialect in fiction. Moreover, it tries to explore the crucial position that this reality holds in a sociolinguistic analysis as well as a literary study. It focuses on Emily Brontë and her sister Charlotte who make use of the 'Yorkshire' dialect in Wuthering Heights and Jane Eyre. Indeed, the two sisters have been in contact with different dialects and languages. They manage to reproduce the Yorkshire dialect in their writing. Because of this deviation in literary texts, characters are stigmatized by some readers as having the worst speech due to the differential access to 'educational opportunities.' Yet, what is the function of this technique? This paper tries to consider the writers' intentions in using dialect in novels as well as to depict the meaning of the use of such a variety of languages. The impact of dialect in fiction is investigated in this study. The researcher thinks it will pave the way for further exploration for anyone interested in how far to go in using dialect in writing, without losing the readers.

Keywords: Brontë, Jane Eyre, language, Wuthering Heights, Yorkshire dialect

Cite as: Mouffak, K. L. 2020). The Yorkshire Dialect Representation in Wuthering Heights and Jane Eyre by Emily and Charlotte Brontë. Arab World English Journal for Translation \& Literary Studies 4 (1) 212-221.

DOI: http://dx.doi.org/10.24093/awejtls/vol4no1.17
\end{abstract}

